\title{
Characteristics of Resistance to Phytophthora Root and Crown Rot in Cucurbita pepo
}

Charles S. Krasnow, Raymond Hammerschmidt, and Mary K. Hausbeck, Department of Plant, Soil, and Microbial Sciences, Michigan State University, East Lansing 48824

\begin{abstract}
Root and crown rot incited by Phytophthora capsici causes considerable annual losses in squash-producing regions in the United States. 'Spineless Perfection' zucchini and 'Cougar' straightneck squash (Cucurbita pepo L.), partially resistant and susceptible to root and crown rot, respectively, were investigated for differences in root and crown physical factors and the histology of crown infection by P. capsici. The $\mathrm{pH}$ and titratable acidity of healthy root and crown tissue from tissue extracts were not significantly different between cultivars $(P=0.05)$. Crude fiber content $(\%)$ of blended and oven-dried root and crown tissue from healthy plants was similar between cultivars. However, dry matter $(\%)$ was highest for Cougar $(P=0.05)$. Colonies of $P$. capsici grown from mycelial plugs in root exudates collected from each cultivar were similar in diameter. Whole mounts and histological sections of healthy and infected crown tissue revealed that vascular bundles and metaxylem vessels were more abundant in crowns of Spineless Perfection than Cougar. Twelve to $48 \mathrm{~h}$ post inoculation (hpi), mycelia in the crown of

each cultivar was limited to the cortex and hypodermal tissue. By 72 hpi, hyphae were observed in the cortex and endodermal tissue of Cougar and were concentrated in the phloem and parenchyma cells surrounding vascular bundles. Mycelia were limited to the outer cortex in Spineless Perfection. Mycelia and occluding material were present in the majority of metaxylem vessels of Cougar but not Spineless Perfection at $92 \mathrm{hpi}$; dissolution of parenchyma cells surrounding vascular bundles was apparent in Cougar. The vascular occlusions observed in Cougar may be responsible for plant wilting, a common disease symptom. Additional straightneck, crookneck, scallop, and acorn squash (C. pepo ssp. ovifera), and zucchini, marrow, and pumpkin (C. pepo ssp. pepo) cultivars were evaluated in a greenhouse study for resistance to root and crown rot. Cucurbita pepo ssp. ovifera cultivars were significantly more susceptible than $C$. pepo ssp. pepo to root and crown $\operatorname{rot}(P<0.0001)$. Growing $C$. pepo ssp. pepo cultivars may be beneficial in an integrated Phytophthora management program.
\end{abstract}

Each growing season, root and crown rot incited by Phytophthora capsici, threatens squash (Cucurbita pepo L.) production in Michigan, a crop valued at \$19.5 million (Anonymous 2015). All commercially available squash and pumpkin cultivars are considered susceptible (Babadoost and Islam 2003; Café-Filho et al. 1995). Severe disease outbreaks have occurred, especially in years with frequent heavy rainfall and temperatures favorable for $P$. capsici (Hausbeck and Lamour 2004). Oospores serve as the primary inoculum source and require specific edaphic conditions for germination (Hausbeck and Lamour 2004; Lamour and Hausbeck 2000). Disease foci frequently develop where soils remain saturated for extended periods and often include poorly drained sections of fields. Motile zoospores are released from sporangia that form on infected plant tissue when free water is present and are a secondary infective propagule (Biles 1995; Granke and Hausbeck 2010). Raised-bed plant culture used in freshmarket vegetable production has reduced losses by improving drainage and limiting soil splash onto aboveground plant parts (Hausbeck and Lamour 2004; Meyer and Hausbeck 2012). However, adherence to strict irrigation schedules and proper placement of drip lines remains important to prevent excessive water and disease (Café-Filho and Duniway 1996). In addition, fungicides can provide protection from root and crown rot when applied to the soil at transplant and via drip irrigation (Kuhn et al. 2011; Meyer and Hausbeck 2013).

Straightneck, crookneck (yellow squash), and zucchini are among the primary squash cultivar groups grown for fresh and processing market sales in Michigan (Zandstra et al. 1986) and are of high economic importance (Paris et al. 2006; Ploetz and Haynes 2000). These cultivar groups have exhibited qualitative differences in susceptibility to Phytophthora

Corresponding author: M. K. Hausbeck; E-mail: hausbec1@msu.edu

Accepted for publication 20 December 2016.

@ 2017 The American Phytopathological Society root and crown rot (Camp et al. 2009; Holmes et al. 2001; Meyer and Hausbeck 2012). Meyer and Hausbeck (2012) observed lower levels of root rot on 'Payroll' zucchini than 'Cougar' straightneck squash grown on raised and flat plant-beds, and suggested the use of cultivars with some degree of resistance as a component of an integrated management program. Appreciable levels of resistance to root rot were also observed in trials in New York and North Carolina with zucchini cultivars compared with yellow squash (Camp et al. 2009; Holmes et al. 2001).

Zucchini roots release greater quantities of organic acids under phosphorous depletion (Gent et al. 2005) and stems and foliage have fewer trichomes (Xiao and Loy 2007) than yellow squash, suggesting that certain biochemical or morphological differences among $C$. pepo cultivar groups may influence susceptibility to Phytophthora root rot. A pepper cultivar resistant to $P$. capsici contains higher quantities of carbohydrates, macroelement nutrients, and dry matter in stem tissue than a susceptible pepper cultivar (Jeun and Hwang 1991). Additionally, $P$. capsici growth is limited in exudate materials and mucigel at the root surface of resistant peppers (Kim and Kim 2009), while the roots and stems of susceptible cultivars are rapidly penetrated (Hwang et al. 1989; Kim and Kim 2009). Identifying traits affecting susceptibility of zucchini and yellow squash to $P$. capsici may provide information useful in squash breeding as all $C$. pepo cultivars cross freely (Erwin and Haber 1929; Paris 1986). The objectives of this study included the following: (i) determine morphological and physiological factors that affect resistance of zucchini to Phytophthora root rot; and (ii) evaluate squash and pumpkin cultivars for resistance to $P$. capsici.

\section{Materials and Methods}

Plant culture, inoculum production, and inoculation. 'Spineless Perfection' zucchini and 'Cougar' straightneck squash previously determined to be less and more susceptible to Phytophthora root rot, respectively, were selected for the study (Meyer and Hausbeck 2012). Plants were grown from seed in $10-\mathrm{cm}$ pots containing coarse vermiculite (Sun Gro, Agawam, MA) or peat potting mixture (Suremix 
Michigan Grower Products Inc., Galesburg, MI) in a research greenhouse located on the campus of Michigan State University in East Lansing, MI. Vermiculite was used to grow plants for tissue analysis and exudation assays so that roots could be rinsed free from soilless mixture. The greenhouse day/night temperatures were $27 / 26^{\circ} \mathrm{C}$ and supplemental lighting was provided from sodium lamps for $16 \mathrm{~h}$ per day. Plants were watered to maintain adequate soil moisture with a 20-20-20 complete fertilizer (Peters, Dublin, OH). In all experiments, 21- to 27- day-old plants (3 to 4 true leaves) were used. Phytophthora capsici isolate SP98 (A2 mating type, originally isolated from pickling cucumber) was selected for inoculum from the culture collection of $\mathrm{M}$. Hausbeck at Michigan State University and maintained on V8-juice agar (140 $\mathrm{ml} \mathrm{V8} \mathrm{juice,} 3 \mathrm{~g} \mathrm{CaCO}_{3}$, and $16 \mathrm{~g}$ agar per liter). Zoospores were produced from 5- to 7-day-old cultures grown under constant fluorescent light by flooding the agar plate with sterile distilled water, chilling at $4{ }^{\circ} \mathrm{C}$ for $30 \mathrm{~min}$, and returning to ambient temperature $\left(21 \pm 1^{\circ} \mathrm{C}\right)$ to permit synchronous release of zoospores. To inoculate plants, a $15-\mathrm{ml}$ zoospore suspension $\left(1 \times 10^{5}\right)$ was poured onto the soil around the base of each plant.

Root and crown tissue analysis. Tissue from uninoculated (healthy) or inoculated zucchini Spineless Perfection and straightneck squash Cougar was obtained by gently uprooting the plants, rinsing the roots under running tap water, rinsing again with sterile distilled water, and blotting the tissue dry with paper toweling. Dry matter (\%) was determined from 1 to $2 \mathrm{~g}$ of healthy root and crown tissue that was dried on pretared aluminum dishes in a gravity oven at $60^{\circ} \mathrm{C}$ for $24 \mathrm{~h}$. Crude fiber content (\%) of roots was determined by blending $10 \mathrm{~g}$ fresh-weight of healthy root and crown tissue in $50 \mathrm{ml}$ of sterile distilled water in a Sorval Omni-mixer for $30 \mathrm{~s}$, vacuum-filtering the residue through miracloth (Millipore, Billerica, MA), and rinsing with sterile distilled water. The crude fiber residue was dried at $60^{\circ} \mathrm{C}$ to a constant weight and the dry weight was recorded. Root and crown tissue $\mathrm{pH}$ and titratable acidity from healthy and infected plants were determined. Plants were inoculated as described above and symptomatic roots developed 2 to 3 days post inoculation (dpi). Healthy or infected root and crown tissue $(5 \mathrm{~g})$ was triturated in $30 \mathrm{ml}$ sterile distilled water using a mortar and pestle and the $\mathrm{pH}$ of the extract was measured with a glass electrode $\mathrm{pH}$ meter (Mettler Toledo, Columbus, $\mathrm{OH}$ ). The extract was poured through two layers of cheesecloth into a 125-ml flask and the residue extracted with two more volumes of sterile distilled water. The extract volume was increased to $100 \mathrm{ml}$ with sterile distilled water then rapidly titrated with $0.005 \mathrm{NaOH}$ using phenolphthalein as an indicator. Tissue acidity was recorded as $\mu$ eq of $\mathrm{NaOH}$ required to titrate the equivalent of $1 \mathrm{~g}$ of root tissue to $\mathrm{pH} 9$. There were 5 to 10 healthy or infected plants of each cultivar per replication and each assay was conducted 3 to 4 times. Plants for each replication were harvested on the same day.

Effect of root exudate on mycelial growth. A method adopted from LaMondia (1995) was used to collect root exudates. Roots of healthy plants of Cougar and Spineless Perfection were harvested, rinsed as previously described, and then excised from the plant at the apex of the crown, immediately below the soil-line. The roots $(2 \mathrm{~g})$ were soaked for $2 \mathrm{~h}$ in $35 \mathrm{ml}$ of sterile distilled water in a sterile acid-washed deep petri dish. Exudate $(6 \mathrm{ml})$ was filter-sterilized through a $0.45-\mu \mathrm{m}$ Millipore filter (EMD Millipore, Billerica, MA) into a sterile $60-\mathrm{mm}$ petri dish and a 5-mm mycelial plug of $P$. capsici taken from the margin of a 5-day-old corn meal agar culture $(17 \mathrm{~g}$ corn meal per liter) was placed into the exudate. Filter-sterile sterile distilled water was used as a control. Colony growth was measured on two axes $72 \mathrm{~h}$ post inoculation (hpi) and the plug diameter was subtracted from the mean. The exudate was confirmed free from bacterial contamination by streaking drops of exudate onto V8 agar. There were seven plates per replicate and the experiment was conducted twice.

Cultivar-group resistance evaluation. Cultivars of squash from the extant C. pepo cultivar groups (Paris 1986) were selected to evaluate host resistance to $P$. capsici (Table 1). The squash plants were grown in peat potting medium in $10-\mathrm{cm}$ pots and plants were inoculated 22 to 23 days post seeding by making a $1-\mathrm{cm}$ deep depression in the potting medium $2 \mathrm{~cm}$ from the crown of the plant and pouring $15 \mathrm{ml}$ of zoospore suspension $\left(1 \times 10^{5}\right)$ into the depression. The plants were rated for disease severity 10 dpi using a scale adapted from Meyer and Hausbeck (2012) where: 1 = healthy appearing plant; 2 = lower leaves wilted with water-soaked tissue observed at the crown; 3 = all leaves wilted with water-soaked tissue and constriction at the crown; $4=$ all leaves wilted with crown

Table 1. Disease severity of squash and pumpkin (Cucurbita pepo) cultivars following inoculation with Phytophthora capsici

\begin{tabular}{|c|c|c|c|c|}
\hline Cultivar name & Cultivar group $^{x}$ & C. pepo subspecies & Seed source ${ }^{y}$ & Disease severity $^{\mathbf{z}}$ \\
\hline Early Summer Crookneck & $\mathrm{Cn}$ & ovifera & Ris & 5.0 \\
\hline Goldstar & $\mathrm{Cn}$ & ovifera & $\operatorname{Rg}$ & 5.0 \\
\hline Cougar & $\mathrm{Sn}$ & ovifera & Ris & 5.0 \\
\hline Multipik & Sn & ovifera & Ris & 5.0 \\
\hline Superpik & Sn & ovifera & $\mathrm{HM}$ & 5.0 \\
\hline Table Queen & Ac & ovifera & Rup & 5.0 \\
\hline Gold Dust & $\mathrm{P}$ & реро & $\mathrm{Sie}$ & 5.0 \\
\hline Taybelle & Ac & ovifera & Rup & 4.9 \\
\hline Bennings Green Tint & $\mathrm{Sc}$ & ovifera & Jon & 4.9 \\
\hline Magic Lantern & $\mathrm{P}$ & реро & Ris & 4.9 \\
\hline Table Ace & Ac & ovifera & SW & 4.7 \\
\hline White Bush Scallop & $\mathrm{Sc}$ & ovifera & Ris & 4.7 \\
\hline Payroll & $\mathrm{Z}$ & pepo & Ris & 4.1 \\
\hline Orange Rave & $\mathrm{P}$ & реро & Sie & 4.1 \\
\hline Spineless Perfection & $\mathrm{Z}$ & реро & Ris & 4.1 \\
\hline Fordhook & $\mathrm{Z}$ & реро & Bur & 3.3 \\
\hline Tivoli & M & pepo & Rup & 2.9 \\
\hline Diablo & $\mathrm{P}$ & pepo & $\mathrm{Sie}$ & 2.9 \\
\hline Vegetable Spaghetti & M & pepo & Rup & 2.3 \\
\hline Dark Green & $\mathrm{Z}$ & pepo & $\mathrm{FM}$ & 1.4 \\
\hline Magda & M & pepo & Jon & 1.2 \\
\hline Hurikan & M & реро & $\mathrm{HM}$ & 1.2 \\
\hline
\end{tabular}

${ }^{\mathrm{x}}$ Cucurbita pepo cultivar type based on Paris (1986). Ac = acorn, $\mathrm{Cn}=$ crookneck, $\mathrm{M}=$ marrow, $\mathrm{P}=$ pumpkin, $\mathrm{Sc}=$ scallop, $\mathrm{Sn}=$ straightneck, $\mathrm{Z}=$ zucchini.

y Bur $=$ W. Atlee Burpee \& Co, Warminster, PA; FM = Ferry-Morse, Norton, MA; HM = Harris Moran, Modesto, CA; Jon = Johnny's Selected Seeds, Winslow,

ME; Rg = Rogers Seeds, Syngenta Co., Boise, ID; Ris = Rispens Seeds, Inc., Beecher, IL; Rup = Rupp Seeds Inc., Wauseon, OH; Sie = Siegers Seed Co., Holland, MI; SW = Seedway, Elizabethtown, PA.

${ }^{\mathrm{z}}$ Disease severity rated $10 \mathrm{dpi}$ on a scale where: $1=$ healthy plant; $2=$ lower leaves wilted with watersoaked tissue observed at the crown; $3=$ all leaves wilted with watersoaked tissue and constriction at the crown; $4=$ all leaves wilted with crown rotted and necrosis and sporulation present on crown and lower stem; and $5=$ dead plant. Value represents the mean of two trials. 
tissue rotted and necrosis and pathogen sporulation observed on crown and lower stem; and $5=$ dead plant. An average disease severity $\leq 2$ was considered to represent partial resistance (Kim et al. 2012). The trial was organized in a completely randomized design with seven plants per cultivar and was conducted twice. Following the termination of each trial, approximately $10 \%$ of plants were arbitrarily selected to isolate $P$. capsici from the root system. Plants were uprooted and the root systems were rinsed with tap water to remove adhering potting medium. Small sections $(5 \mathrm{~mm})$ of symptomatic roots were excised, dipped into $70 \%$ ethanol for $3 \mathrm{~s}$, blotted dry with paper towels, and plated onto BARP-amended V8-agar (Krasnow and Hausbeck 2015). There were three segments of root tissue plated from each plant. Colonies that developed on the amended media were transferred to V8-agar and confirmed as $P$. capsici using sporangial

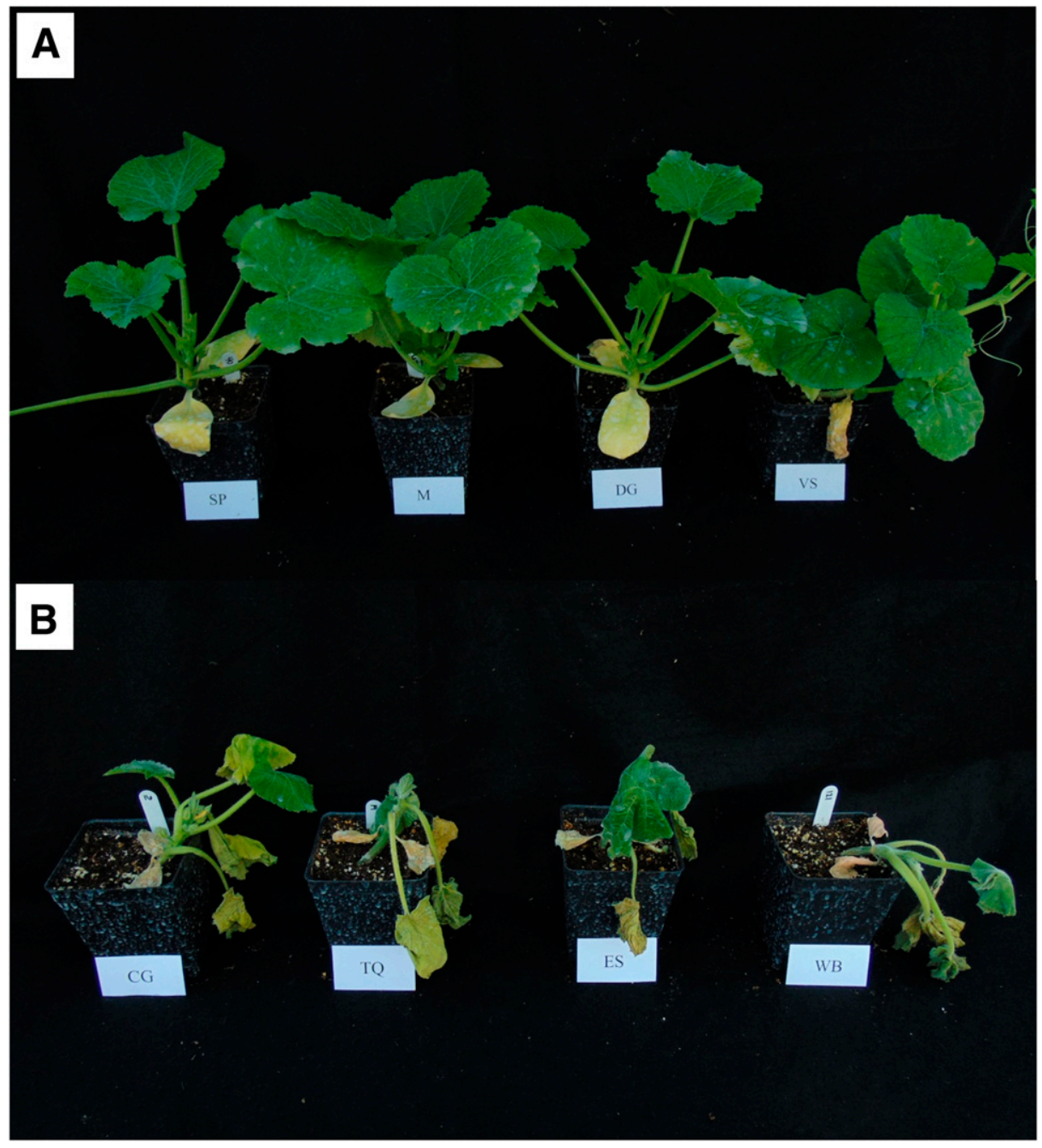

Fig. 1. Cucurbita pepo A, ssp. pepo and B, ssp. ovifera plants 8 days post inoculation with Phytophthora capsici in greenhouse evaluation for root and crown rot resistance. $\mathrm{SP}=$ Spineless Perfection, DG = Dark Green, $\mathrm{M}=$ Magda, VS = Vegetable Spaghetti, CG = Cougar, TQ = Table Queen, ES = Early Summer, Crookneck, WB = White Bush Scallop.
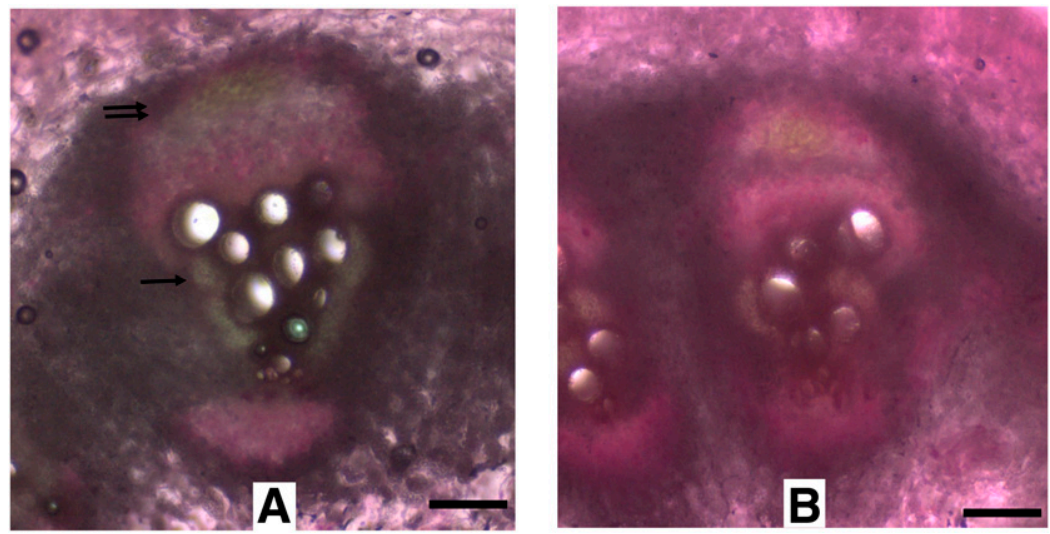

Fig. 2. Photomicrograph (40x) of healthy vascular bundle from whole-mount section of crown tissue of A, Spineless Perfection zucchini (field resistant) and B, Cougar straightneck squash (susceptible). Note the quantity of metaxylem vessels (arrow) and thick bundle sheath (double arrow) of Spineless Perfection. Bars $=20 \mu \mathrm{m}$. 
morphology and the key of Waterhouse (1963). The mating type and mefenoxam sensitivity of the recovered isolates was determined (Lamour and Hausbeck 2000) to confirm phenotypic similarity to the isolate used for inoculation.

Light microscopy and histology. Healthy and infected plants of each cultivar were studied to observe differences in the infection process and crown tissue morphology. Root and crown tissue from plants of each cultivar grown in peat potting medium were harvested

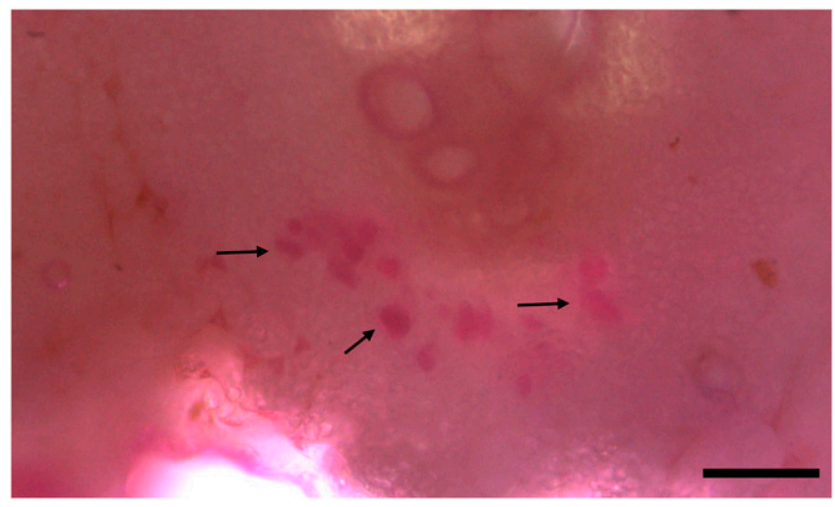

Fig. 3. Infection and development of hyphae of Phytophthora capsici in the inner phloem tissue of Cougar. Dense staining (arrows) due to P. capsici mycelium. Bar $=10 \mu \mathrm{m}$
0, 24, 48, 72, and $92 \mathrm{hpi}$ and rinsed as described above. Transverse and tangential whole mounts of tissue $\sim 0.1 \mathrm{~mm}$ thick from the crown-primary root region were excised with a razor blade, placed on a glass microscope slide, stained with $0.005 \%$ acid fuchsin in 1:1 sterile distilled water:lactic acid, and viewed using brightfield microscopy. For histological examination, plants were harvested 0 , $12,24,48,72$, and 92 hpi and crown tissue pieces were fixed in formalin, acetic acid, alcohol, and water (10:5:50:35), and dehydrated through a tertiary butyl alcohol series. The tissue was embedded in paraffin (melting point $52^{\circ} \mathrm{C}$ ), and $12-\mu \mathrm{m}$ sections were made using a rotary microtome. Sections were affixed to glass microscope slides and stained with safranin and fast green (Jensen 1962). For each time point, crown samples from 5 to 10 plants were prepared and $\sim 10$ sections from each sample were observed. Photomicrographs were taken with a microscope camera (U-CMAD3, Olympus, Tokyo, Japan).

Statistical analysis. Data were analyzed using the Statistical Analysis System v. 9.4 (SAS Institute Inc., Cary, NC). Dry matter (\%), crude fiber content, tissue $\mathrm{pH}$, and titratable acidity were compared between Spineless Perfection and Cougar with ANOVA using the Proc Mixed procedure. The diameter of $P$. capsici mycelial growth in root exudate was analyzed using ANOVA $(P=0.05)$. Data from sterile distilled water controls were not included in the analysis because there was no measurable mycelial growth in this treatment. Differences in disease severity values for $C$. pepo cultivars, cultivar groups, and subspecies in the greenhouse cultivar resistance evaluation were analyzed with Proc Mixed. Normality of residual data were assessed using Proc Univariate and Proc Gplot. Data from each trial were pooled prior to
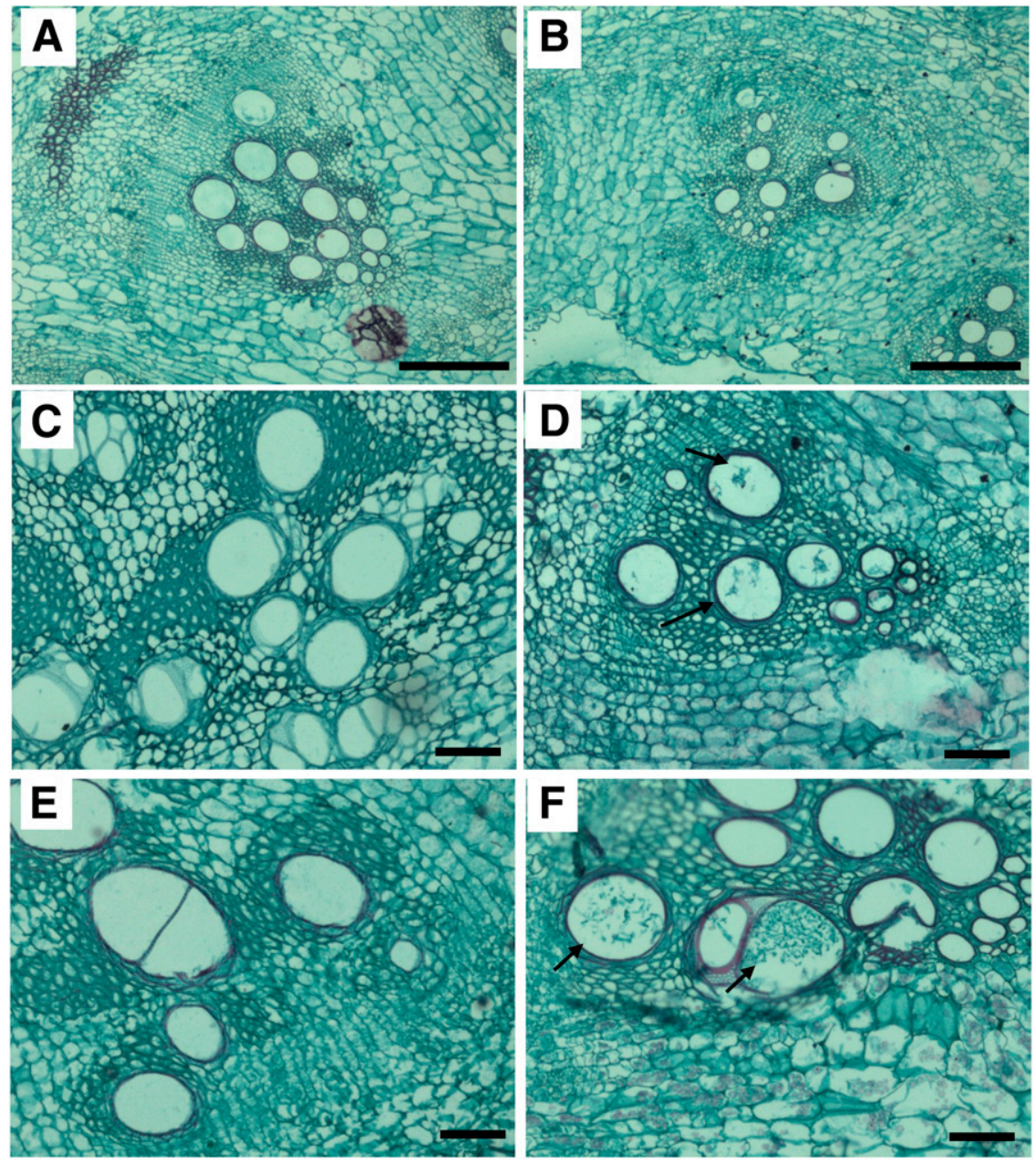

Fig. 4. Crown sections of A, C, E, Spineless Perfection zucchini and B, D, F, Cougar straightneck squash stained with safranin-fast green. A, B, Healthy crown tissue. Bars = $40 \mu \mathrm{m}$. C, D, Crown tissue $48 \mathrm{~h}$ post inoculation with Phytophthora capsici. Mycelium and occluding substances (arrow) present in xylem in D. Bars $=10 \mu \mathrm{m}$. E, F, crown tissue $72 \mathrm{~h}$ post inoculation with $P$. capsici. Dense mycelium (arrows) present in xylem vessel in F. Bars $=10 \mu \mathrm{m}$. 
analysis as assumptions for homogeneity of variance were met. A slice statement was used when interactions of simple main effects were found to be significant. The likelihood of a subspecies having an average disease severity value $\geq 2$ was determined with $\chi^{2}$ analysis and odds ratios using Proc Freq and Cochran-Mantel-Haenszel test statistics. Cucurbita pepo cultivar group comparisons were made using Proc Freq.

\section{Results}

Root and crown assay. The roots of healthy plants harvested for root assays were white and turgid and symptomatic roots were brown or discolored with water soaking evident on tissues including the taproot, crown, and lateral roots at the point of emergence from the crown. The dry matter $(\%)$ of healthy roots of Cougar was significantly higher than Spineless Perfection with values of 7.6 and $7.2 \%$, respectively $(P=$ 0.04 ; data not shown). Crude fiber content was not significantly different between cultivars $(P=0.39)$, averaging 3.1 and $3.5 \%$ for Cougar and Spineless Perfection, respectively (data not shown). $\mathrm{pH}$ values for healthy and diseased roots of Spineless Perfection and Cougar were not significantly different between cultivars (mean $\mathrm{pH}$ 6.7; data not shown). Titratable acidity of healthy roots of each cultivar was lower than that for diseased roots (data not shown). Diseased roots contained 6.4 and $24.5 \%$ greater acidity than healthy roots for Spineless Perfection and Cougar, respectively. However, differences between cultivars for healthy $(P=0.13)$ and diseased $(P=0.78)$ roots were not significant.

Effect of root exudate on mycelial growth. When $P$. capsici was grown in root exudate of Cougar and Spineless Perfection, the average diameter of mycelial growth was 7.3 and $6.7 \mathrm{~mm}$, respectively (data not shown). These differences were not significant when analyzed using ANOVA $(P=0.41)$; however, they were greater than the growth observed for the sterile distilled water control (mean $0.0 \mathrm{~mm}$ diameter).

Cultivar group resistance evaluation. Wilt developed rapidly on C. pepo ssp. ovifera cultivars in the greenhouse screen for resistance (Fig. 1). By 3 dpi, $50 \%$ of the C. pepo ssp. ovifera cultivars had at least one plant with wilt symptoms (data not shown). At 4 dpi, all C. pepo ssp. ovifera cultivars had plants displaying symptoms of wilt, while plants of only one C. pepo ssp. pepo cultivar developed symptoms. The average disease severity for $C$. pepo ssp. ovifera cultivars was 4.9 at $10 \mathrm{dpi}$ (Table 1). Cucurbita pepo ssp. pepo cultivars displayed lower disease severity, averaging 3.1 among cultivars. 'Dark Green', 'Magda', and 'Hurikan' had the lowest disease severity values at 1.4, 1.2, and 1.2, respectively (Table 1). Zucchini cultivars had an average disease severity of 3.2, significantly lower than the average for crookneck squash cultivars (5.0) and straightneck squash (5.0) when the cultivar groups were compared using ANOVA $(P=0.05)$. The mean disease severity for $C$. pepo ssp. ovifera cultivars was significantly higher than for $C$. pepo ssp. pepo cultivars $(P<0.0001)$. Cultivars of $C$. pepo ssp. pepo were less likely to have disease severity $\geq 2$ compared with $C$. pepo ssp. ovifera $\left(\chi^{2}=62.0 ; P<0.0001\right)$.
Symptom development and infection process. When plants were inoculated with a zoospore suspension of $P$. capsici, the lower leaves of Cougar began to wilt 2 to 3 dpi. Water soaking of crown tissue was usually observed concurrently with the initial wilt symptoms. By $4 \mathrm{dpi}$, wilt was severe in Cougar, and sunken lesions and constriction were observed at the crown and lower stem. Plants often lodged 5 to 6 dpi and constriction and necrosis was advanced to the lower stem. Plant death occurred by $8 \mathrm{dpi}$; leaves withered with constriction and stem necrosis evident from the soil-line to the apical meristem and base of the lowermost petioles. P. capsici sporulated profusely at the soilline on crown and lower stem tissue. Yellowing of lower leaves of Spineless Perfection was observed 6 dpi with no additional symptoms; incipient wilt was occasionally observed $8 \mathrm{dpi}$.

Crown tissue of Cougar contained an average of 6.5 vascular bundles and Spineless Perfection contained 8.5 (data not shown). Individual vascular bundles of Spineless Perfection apparently contained more metaxylem vessels than Cougar (Fig. 2A and B). In whole mounts of infected plants, mycelium of $P$. capsici was observed in hypodermal tissue of Cougar and Spineless Perfection and at the point of emergence of lateral roots by $24 \mathrm{hpi}$. By $48 \mathrm{hpi}$, the epidermal tissue of Cougar exhibited orange pigmentation and the discoloration extended into the cortex at the point of infection. Mycelium and occluding material were present in many of the metaxylem vessels of Cougar at 72 hpi and hyphae had ramified through the tissue and were observed in the medulla. Occluding material was not observed as frequently in metaxylem vessels of Spineless Perfection as in Cougar. Mycelia were observed exiting stomata on the crown surface of tangential sections of both cultivars at 72 hpi. Mycelial growth was not dense in the cortex of either cultivar at $72 \mathrm{hpi}$, but was abundant in the phloem and parenchyma surrounding vascular bundles of Cougar (Fig. 3). At 92 hpi, mycelia were present through the crown tissue of Cougar. Host cell walls were thin, some were broken, and the walls had lost birefringence. Dissolution of cortex cell walls was apparent and cortex tissue was compressed. Vessels were almost completely occluded with mycelium and occluding materials. The cortex cells of Spineless Perfection were not compressed or broken and the majority of vessels were not occluded. Vascular bundles and bundle sheaths appeared structurally unaffected at 92 hpi in both cultivars.

In histological sections, xylary fibers adjacent to xylem vessels appeared more compact in Spineless Perfection than Cougar (Fig. 2-A, B). Mycelium and occluding substances were difficult to observe at early stages of infection and sections of each cultivar appeared similar until 48 hpi (Fig. 4-A-D). At 72 hpi, destruction of phloem cells and cells surrounding xylem vessels of Cougar was apparent and some vessels were filled with mycelia (Fig. 4-E). Vascular tissue and surrounding parenchyma tissue of Spineless Perfection appeared unaffected (Fig. 4-F). Tyloses, occluding material, and mycelia were present in the majority

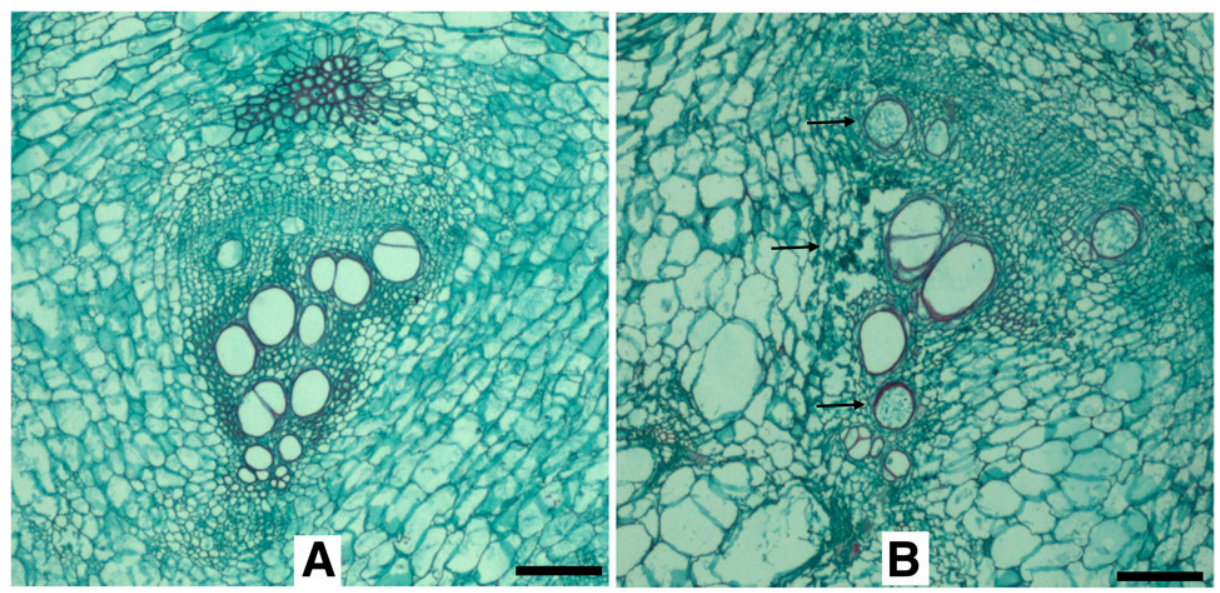

Fig. 5. Sections of crown tissue of A, Spineless Perfection zucchini and B, Cougar straightneck squash stained with safranin-fast green $92 \mathrm{~h}$ post inoculation with Phytophthora capsici. Note the occluded vessels and apparent deterioration of parenchyma tissue surrounding metaxylem (arrows) in B). Bars $=20 \mu \mathrm{m}$. 
of Cougar metaxylem vessels by $92 \mathrm{hpi}$, but were absent from most vessels of Spineless Perfection (Fig. 5). Xylem vessels and bundle sheaths in both cultivars were similar in appearance at $92 \mathrm{hpi}$ to the healthy controls.

\section{Discussion}

The high susceptibility of yellow squash to Phytophthora crown and root rot relative to other summer squash cultivar groups has been observed in research trials (Camp et al. 2009; Holmes et al. 2001; Meyer and Hausbeck 2012) and reported epiphytotics (Café-Filho and Duniway 1995; Crossan et al. 1953; Jones and McGovern 1994; Tompkins and Tucker 1941). Differences reported among zucchini and yellow squash cultivar groups in trichome size and abundance (Xiao and Loy 2007), cucurbitacin content (Sharma and Hall 1971), and ability to uptake nutrients (Gent et al. 2005) suggest that there may be biochemical or morphological differences that relate to susceptibility to $P$. capsici. Cougar and Spineless Perfection had similar fiber content $(\%)$ in this study although dry matter $(\%)$ was highest for Cougar. NeSmith (1993) determined that root and shoot dry weight for 'Senator' zucchini was significantly higher than 'Dixie' crookneck, and the earlier growth stage at harvest in the current study may have influenced dry matter accumulation. Acidity and $\mathrm{pH}$ of diseased and healthy root and crown tissue of Cougar and Spineless Perfection were similar. Cucurbita pepo is known to produce numerous organic acids in the root system (Kursanov and Kulaeva 1957). Although zucchini was able to exude higher levels of citric acid under phosphorus depletion than yellow squash, acid concentration in root tissue was not different among cultivar groups grown under normal nutrition (Gent et al. 2005). Some fungal pathogens are known to change tissue $\mathrm{pH}$ during pathogenesis (Venning and Crandall 1954) and the limited $\mathrm{pH}$ change in $P$. capsici infected squash roots may be due to differences in infection processes or plant parts infected. Infected tissue from the margin of a $P$. capsici lesion on zucchini fruit had a $\mathrm{pH}$ approximately 1.5 units higher than noninfected fruit (pH 6.4) (C. Krasnow and M. Hausbeck, unpublished data).

Cucurbita pepo is a species highly polymorphic for fruit shape that has traditionally been grouped based on fruit morphology and color (Castetter 1925; Whitaker and Davis 1962). The cultivar grouping has been refined more recently using fruit shape (Paris 1986). Phenotypes of six isozyme systems present throughout root, hypocotyl, and leaf tissue of $C$. pepo cultivars (Ignart and Weeden 1984) differentiated major cultivar groups into two subspecies: ovifera and pepo (Decker 1988; Paris et al. 2006). The subspecies designation was additionally confirmed with genetic markers (Bates et al. 1990). Cucurbita pepo ssp. ovifera contains cultivar groups scallop, acorn, crookneck, and straightneck squash, while marrow, zucchini, cocozelle, and pumpkin are within $C$. pepo ssp. pepo (Paris et al. 2006). Crookneck, straightneck, and acorn squash cultivars in $C$. pepo ssp. ovifera are highly susceptible to $P$. capsici (Café-Filho and Duniway 1995; Crossan et al. 1953; Holmes et al. 2001; Jones and McGovern 1994; Krasnow and Hausbeck 2017; Meyer and Hausbeck 2012; Tompkins and Tucker 1941) and C. pepo ssp. pepo cultivars of zucchini and vegetable spaghetti (marrow) often display field resistance (Camp et al. 2009; Holmes et al. 2001; Krasnow and Hausbeck 2017; Meyer and Hausbeck 2012). The relationship of $C$. pepo subspecies and field resistance to $P$. capsici may be specific to oomycete pathogens; Didymella bryoniae (Keinath 2014), Fusarium spp. (Martyn and McLaughlin 1983; Sumner 1976), Cladosporium cucumerinum (Strider and Konsler 1965), Erwinia tracheiphila (Rand and Enlows 1916), and root knot nematodes (Thomason and McKinney 1959) cause disease on $C$. pepo cultivars without a relation between disease severity and the $C$. pepo subspecies. The oomycete Pseudoperonospora cubensis, however, has been observed to cause less severe disease symptoms on C. pepo ssp. pepo than on ssp. ovifera (Holmes et al. 2015). Cucurbita pepo ssp. ovifera and ssp. pepo have different centers of origin and likely have separate wild progenitor Cucurbita spp. (Bates et al. 1990), which may be a factor in susceptibility to oomycete pathogens. The isozyme phenotypes of pumpkin cultivars are more variable than other $C$. pepo ssp. pepo cultivar groups (Ignart and Weeden 1984) and the presence of small fruited gourds in C. pepo ssp. ovifera (Decker 1988; Paris et al. 2006) may relate to the high disease levels observed on 'Magic Lantern' and 'Gold Dust' mini pumpkin. Additionally, further testing of
C. pepo ssp. pepo cultivars under field conditions would be beneficial as prolonged inoculum contact is known to influence disease severity (Barksdale et al. 1984).

Wilt develops on cucurbits after infection by pathogens that occlude or rupture vascular tissue (Main and Walker 1971; Martyn and McLaughlin 1983; Palodhi and Sen 1979). In the current study, mycelia and occluding substances were observed in vessels of Cougar squash plants at the initiation of wilt symptoms induced by $P$. capsici and were present more frequently than in infected Spineless Perfection plants. Vascular occlusions and mycelial growth in xylem vessels of resistant squash cultivars infected by Fusarium oxysporum are also limited (Martyn and McLaughlin 1983). Similarly, occlusions of stem xylem vessels were suggested as the cause of wilt in a susceptible pepper cultivar after infection by $P$. capsici but were infrequently observed in a resistant cultivar (Kim and Kim 2009). The phloem tissue, parenchyma, and meristem cells adjacent to vascular bundles of Cougar and to a lesser extent in Spineless Perfection were apparently preferential for growth of $P$. capsici due to the intensity of hyphal staining in these regions. Phloem parenchyma has been suggested to be involved in solute storage in C. pepo (Duloy et al. 1962). Nutrients or sugars located in the phloem parenchyma and the thin cell walls of vascular meristem cells (Esau 1965) may be preferential for colonization by $P$. capsici in infected $C$. pepo roots and crown. Cortical parenchyma tissue and epidermal cells of pepper stems were completely degraded after infection by $P$. capsici (Kim and Hwang 1989). The dense parenchyma cells in the endodermal region of Spineless Perfection and numerous lignified metaxylem vessels may provide structural support of infected crown tissue, preventing collapse and mechanical breakage of xylem tissue that would increase resistance to water flow (Powers 1954). Deterioration of parenchyma cells surrounding the xylem in Cougar may have a role in symptom development if vessels break under the weight of the aboveground plant due to reduced cellular support. Marks and Mitchell (1971) observed that alfalfa tolerant of $P$. megasperma had a thicker central stele and greater lateral root production than cultivars susceptible to root rot. If occlusions or xylem disruption are the cause of wilt in P. capsici infected squash, they are likely localized at the site of infection; severely wilted squash plants fully recovered in 1 to $2 \mathrm{~h}$ after the stems of infected, symptomatic plants were excised above the crown lesion and placed into distilled water (C. Krasnow and M. Hausbeck, personal observation). Localized obstruction of vascular tissue of $P$. nicotianae infected tobacco was also observed (Powers 1954).

The field resistance of $C$. pepo ssp. pepo may be beneficial in an integrated Phytophthora management program as resistant squash cultivars are not commercially available. In Michigan, repeat fungicide applications are frequently made during fresh-market squash production to limit Phytophthora root rot; however, the resistance of the cultivar planted is usually not considered when determining application intervals. Yeh and Kim (1991) recommended that the intervals between sprays to control pepper Phytophthora blight be based on the resistance of the cultivar. Applying fungicides at an increased interval may reduce fungicide costs and improve plant health and yield for $C$. pepo ssp. pepo cultivars with field resistance to Phytophthora root rot.

\section{Acknowledgments}

The authors would like to thank Samantha Borowski for technical assistance. This material is based upon work that is supported by the National Institute of Food and Agriculture, U.S. Department of Agriculture under award number 201551181-24285.

\section{Literature Cited}

Anonymous. 2015. Vegetables: 2015 Summary. USDA-NASS and Mann Lib., Cornell Univ., Ithaca NY. http://usda.mannlib.cornell.edu/usda/nass/VegeSumm// 2010s/2016/VegeSumm-02-04-2016.pdf.

Babadoost, M., and Islam, S. Z. 2003. Fungicide seed treatment effects on seedling damping-off of pumpkin caused by Phytophthora capsici. Plant Dis. 87:63-68.

Barksdale, T., Papavizas, G., and Johnston, S. 1984. Resistance to foliar blight and crown rot of pepper caused by Phytophthora capsici. Plant Dis. 68: 506-508

Bates, D., Robinson, R., and Jeffrey, C. 1990. Biology and Utilization of the Cucurbitaceae. Cornell Univ. Press, Ithaca, NY. 
Biles, C. L. 1995. Phytophthora capsici zoospore infection of pepper fruit in various physical environments. Proc. Okla. Acad. Sci. 75:1-5.

Café-Filho, A. C., and Duniway, J. M. 1995. Dispersal of Phytophthora capsici and $P$. parasitica in furrow-irrigated rows of bell pepper, tomato and squash. Plant Pathol. 44:1025-1032.

Café-Filho, A. C., Duniway, J. M., and Davis, R. M. 1995. Effects of the frequency of furrow irrigation on root and fruit rots of squash caused by Phytophthora capsici. Plant Dis. 79:44-48.

Café-Filho, A. C., and Duniway, J. M. 1996. Effect of location of drip irrigation emitters and position of Phytophthora capsici infections in roots on Phytophthora root rot of pepper. Phytopathology 86:1364-1369.

Camp, A., Lange, H., Reiners, S., Dillard, H., and Smart, C. 2009. Tolerance of summer and winter squash lines to Phytophthora blight, 2008. Plant Dis. Manage. Rep. 3:V022.

Castetter, E. 1925. Horticultural groups of cucurbits. Proc. Am. Soc. Hortic. Sci. 22:338-340.

Crossan, D. F., Haasis, F. A., and Ellis, D. E. 1953. Phytophthora blight of summer squash in North Carolina. Phytopathology 43:469.

Decker, D. S. 1988. Origin(s), evolution, and systematics of Cucurbita pepo (Cucurbitaceae). Econ. Bot. 42:4-15.

Duloy, M., Mercer, F., and Rathgeber, N. 1962. Studies in translocation III. The cytophysiology of the phloem of Cucurbita pepo. Aust. J. Biol. Sci. 15:459-467.

Erwin, A. T., and Haber, E. S. 1929. Species and varietal crosses in cucurbits. Iowa Ag. Exp. Sta. Bull. 263:841-872.

Esau, K. 1965. Plant Anatomy, 2nd Ed. J. Wiley \& Sons, New York, NY.

Gent, M. P., Parrish, Z. D., and White, J. C. 2005. Nutrient uptake among subspecies of Cucurbita pepo L. is related to exudation of citric acid. J. Am. Soc. Hortic. Sci. 130:782-788.

Granke, L. L., and Hausbeck, M. K. 2010. Effects of temperature, concentration, age, and algaecides on Phytophthora capsici zoospore infectivity. Plant Dis. 94:54-60.

Hausbeck, M. K., and Lamour, K. H. 2004. Phytophthora capsici on vegetable crops: Research progress and management challenges. Plant Dis. 88:1292-1303.

Holmes, G., Lancaster, M., Rodriguez, R., and Redman, R. 2001. Relative susceptibility of cucurbit and solanaceous crops to Phytophthora blight, 2000. Biol. Cult. Tests 16:V87.

Holmes, G. J., Ojiambo, P. S., Hausbeck, M. K., Quesada-Ocampo, L., and Keinath, A. P. 2015. Resurgence of cucurbit downy mildew in the United States: a watershed event for research and extension. Plant Dis. 99:428-441.

Hwang, B., Kim, W., and Kim, W. 1989. Ultrastructure at the host-parasite interface of Phytophthora capsici in roots and stems of Capsicum annuum. J. Phytopathol. 127:305-315

Ignart, F., and Weeden, N. 1984. Allozyme variation in cultivars of Cucurbita pepo L. Euphytica 33:779-785.

Jensen, W. A. 1962. Botanical Histochemistry: Principles and Practice. W. H. Freeman, San Francisco, CA.

Jeun, Y. C., and Hwang, B. K. 1991. Carbohydrate, amino-acid, phenolic and mineral nutrient contents of pepper plants in relation to age-related resistance to Phytophthora capsici. Phytopathol. Z. 131:40-52.

Jones, J. P., and McGovern, R. J. 1994. Effect of temperature and fungicides on the development of Phytophthora blight and fruit rot of squash. Proc. Fla. State Hortic. Soc. 107:147-150.

Keinath, A. P. 2014. Differential susceptibility of nine cucurbit species to the foliar blight and crown canker phases of gummy stem blight. Plant Dis. 98:247-254.

Kim, M. J., Shim, C. K., Kim, Y. K., Jee, H. J., Hong, S. J., Park, J. H., Lee, M. H., and Han, E. J. 2012. Screening of resistance melon germplasm to Phytotpthora rot caused by Phytophthora capsici. Kor. J. Crop Sci. 57:389-396.

Kim, S. G., and Kim, Y. H. 2009. Histological and cytological changes associated with susceptible and resistant responses of chili pepper root and stem to Phytophthora capsici infection. Plant Path. J. 25:113-120.

Kim, W., and Hwang, B. 1989. Histological changes in the roots and stems of pepper plants infected with Phytophthora capsici. Kor. J. Plant Pathol. 5:40-48.

Krasnow, C. S., and Hausbeck, M. K. 2015. Pathogenicity of Phytophthora capsici to brassica vegetable crops and biofumigation cover crops (Brassica spp.). Plant Dis. 99:1721-1726.

Krasnow, C. S., and Hausbeck, M. K. 2017. Evaluation of winter squash cultivars for resistance to Phytophthora root rot, 2015. Plant Dis. Manag. Rep. (in press). Online publication.
Kuhn, P., Babadoost, M., Thomas, D., Ji, P., McLean, H., Hert, A., Tory, D., and Tally, A. 2011. Evaluation of drip applications of Revus in fungicide programs for management of Phytophthora blight (Phytophthora capsici) on bell pepper and squash. (abst.). Phytopathology 101:S94.

Kursanov, A., and Kulaeva, O. 1957. Metabolism of organic acids in the pumpkin roots. Физиол. раст. 4:322-331.

LaMondia, J. 1995. Hatch and reproduction of Globodera tabacum tabacum in response to tobacco, tomato, or black nightshade. J. Nematol. 27:382-386.

Lamour, K. H., and Hausbeck, M. K. 2000. Mefenoxam insensitivity and the sexua stage of Phytophthora capsici in Michigan cucurbit fields. Phytopathology 90: 396-400.

Main, C. E., and Walker, J. C. 1971. Physiological responses of susceptible and resistant cucumber to Erwinia tracheiphila. Phytopathology 61:518-522.

Marks, G., and Mitchell, J. 1971. Factors involved with the reaction of alfalfa to root rot caused by Phytophthora megasperma. Phytopathology 61:510-514.

Martyn, R. D., and McLaughlin, R. J. 1983. Susceptibility of summer squash to the watermelon wilt pathogen (Fusarium oxysporum f. sp niveum). Plant Dis. 67: 263-266.

Meyer, M. D., and Hausbeck, M. K. 2012. Using cultural practices and cultivar resistance to manage Phytophthora crown rot on summer squash. Hortsci. 47: 1080-1084

Meyer, M. D., and Hausbeck, M. K. 2013. Using soil-applied fungicides to manage Phytophthora crown and root rot on summer squash. Plant Dis. 97:107-112.

NeSmith, D. S. 1993. Transplant age influences summer squash growth and yield. Hortsci. 28:618-620.

Palodhi, P. R., and Sen, B. 1979. Role of tylose development in a muskmelon disease caused by Fusarium solani. Plant Dis. Rept. 63:584-586.

Paris, H. S. 1986. A proposed subspecific classification for Cucurbita pepo. Phytologia 61:113-138.

Paris, H. S., Burger, Y., and Schaffer, A. A. 2006. Genetic variability and introgression of horticulturally valuable traits in squash and pumpkins of Cucurbita pepo. Isr. J. Plant Sci. 54:223-231.

Ploetz, R. C., and Haynes, J. L. 2000. How does Phytophthora capsici survive in squash fields in southeastern Florida during the off-season. Proc. Fla. State Hortic. Soc 113:211-215.

Powers, H. R. 1954. The mechanism of wilting in tobacco plants affected by black shank. Phytopathology 44:513-521.

Rand, F. V., and Enlows, E. 1916. Transmission and control of bacterial wilt of cucurbits. J. Ag. Res. 6:417-434.

Sharma, G., and Hall, C. 1971. Influence of cucurbitacins, sugars, and fatty acids on cucurbit susceptibility to spotted cucumber beetle. Am. Soc. Hortic. Sci. J. 96:675-680.

Strider, D. L., and Konsler, T. R. 1965. An evaluation of the Cucurbita for scab resistance. Plant Dis. Rept. 49:388-391.

Sumner, D. R. 1976. Etiology and control of root-rot of summer squash in Georgia. Plant Dis. Rept. 60:923-927.

Thomason, I. J., and McKinney, H. E. 1959. Reaction of some cucurbitaceae to root knot nematodes (Meloidogyne spp.). Plant Dis. Rept. 43:448-450.

Tompkins, C. M., and Tucker, C. M. 1941. Root rot of pepper and pumpkin caused by Phytophthora capsici. J. Ag. Res. 63:417-426.

Venning, F., and Crandall, B. 1954. A parasitism mechanism of the kenaf anthracnose organism related to the hydrogen ion concentration in the tissues of the host. Phytopathology 44:465-468.

Waterhouse, G. M. 1963. Key to the species of Phytophthora de Bary. Mycol. Pap. 92:1-22.

Whitaker, T., and Davis, G. 1962. Cucurbits - Botany, Cultivation, and Utilization. Interscience Publ. Inc, New York, NY.

Xiao, Q., and Loy, J. B. 2007. Inheritance and characterization of a glabrous trait in summer squash. J. Am. Soc. Hortic. Sci. 132:327-333.

Yeh, W., and Kim, C. 1991. Integrated management of Phytophthora blight of redpepper by host resistance and fungicide application. Kor. J. Plant Pathol. 7 226-229 (Korea Republic).

Zandstra, B., Grafius, E., and Stephens, C. 1986. Commercial Vegetable Recommendations: Pumpkins, Squashes, and Gourds. MSU Ext. Bull. E-1953. Michigan State. Univ., East Lansing, MI. 